\title{
Polycyclic aromatic hydrocarbon in urban soils of an Eastern European megalopolis: distribution, source identification and cancer risk evaluation
}

\author{
George Shamilishvily ${ }^{1}$, Evgeny Abakumov ${ }^{1}$, and Dmitriy Gabov ${ }^{2}$ \\ ${ }^{1}$ St. Petersburg State University, Dept. of Applied Ecology, St. Petersburg, Russia \\ ${ }^{2}$ Institute of Biology, Komi Scientific Centre, Russian Academy of Sciences, Syktyvkar, Russia
}

Correspondence: George Shamilishvily (george199207@gmail.com)

Received: 27 May 2017 - Discussion started: 16 August 2017

Revised: 17 March 2018 - Accepted: 16 April 2018 - Published: 23 May 2018

\begin{abstract}
This study explores qualitative and quantitative composition of 15 priority polycyclic aromatic hydrocarbons (PAHs) in urban soils of some parkland, residential and industrial areas of the large industrial centre of Saint Petersburg (Russian Federation) in Eastern Europe. The aim of the study was to test the hypothesis on the PAH loading differences among urban territories with different land use scenarios. Benzo(a)pyrene toxic equivalency factors (TEFs) were used to calculate $\mathrm{BaP}_{\mathrm{eq}}$ in order to evaluate carcinogenic risk of soil contamination with PAHs. Results of the study demonstrated that soils within residential and industrial areas are characterized by common loads of PAHs generally attributed to high traffic activity in the city. Considerable levels of soil contamination with PAHs were noted. Total PAH concentrations ranged from 0.33 to $8.10 \mathrm{mg} \mathrm{kg}^{-1}$. A larger portion of high-molecular-weight PAHs along with determined molecular ratios suggest the predominance of pyrogenic sources, mainly attributed to combustion of gasoline, diesel and oil. Petrogenic sources of PAHs have a significant portion and define the predominance of low-molecular-weight PAHs associated with petroleum, such as phenanthrene. Derived concentrations of seven carcinogenic PAHs as well as calculated $\mathrm{BaP}_{\text {eq }}$ were multiple times higher than reported in a number of other studies. The obtained $\mathrm{BaP}_{\mathrm{eq}}$ concentrations of the sum of 15 PAHs ranged from 0.05 to $1.39 \mathrm{mg} \mathrm{kg}^{-1}$. A vast majority of examined samples showed concentrations above the safe value of $0.6 \mathrm{mg} \mathrm{kg}^{-1}$ (CCME, 2010). However, estimated incremental lifetime risks posed to the population through distinct routes of exposure were in an acceptable range. One-way ANOVA results showed significant differences in total PAHs and the sum of seven carcinogenic PAH
\end{abstract}

concentrations as well as in levels of FLU, PHE, FLT, PYR, $\mathrm{BaA}, \mathrm{CHR}, \mathrm{BbF}, \mathrm{BaP}$ and BPE among parkland, residential and industrial land uses, suggesting the influence of the land use factor.

\section{Introduction}

There is a huge variety of toxic organic compounds, but in environment control practices around the world evaluation of contaminated areas is often based on priority listed pollutants. This list includes, for example, polycyclic aromatic hydrocarbons (PAHs), which are ubiquitous organic pollutants in the environment (Wilcke, 2000). PAHs are a large group of aromatic organic compounds consisting of several hundred individual homologues and isomers containing at least two condensed aromatic rings. Their input to the environment has both natural and anthropogenic origins. Natural sources include releases from vegetation fires, diagenetic processes and volcanic exhalations (ATSDR, 1995; Wilcke, 2000). In turn, anthropogenic PAHs occur from pyrolytic processes, especially incomplete combustion of organics during industrial activities, domestic heating, waste incineration, transportation and power generation (ATSDR, 1995; Wilcke, 2000). It is believed that by far most PAHs are released into the environment by anthropogenic combustion of wood and fossil fuels (Wilcke, 2000). Soil contamination with PAHs is even noted in such remote places as Antarctica, basically near the polar stations. However, the origin of PAHs in Antarctic soils is questioned, considering that it could have both natural sources, for example, decomposition 
of organic matter, and anthropogenic sources, such as fuel combustion, oil spills and long-range transport of solid atmospheric particles containing PAH mixtures (Abakumov et al., 2014, 2015). Detection of some individual PAHs is of the most environmental importance because of the established carcinogenic, mutagenic and teratogenic effects on living organisms and in humans particularly (Yu, 2002; Guo et al., 2013). There have been 16 PAHs listed as priority contaminants by both the US Environmental Protection Agency (US EPA) and the European Union (EU). Among them, seven compounds, i.e., benzo(a)anthracene, chrysene, benzo(a)pyrene, benzo(b)fluoranthene, benzo(k)fluoranthene, dibenz(a,h)anthracene and indeno(1,2,3-cd)pyrene are considered to be probable human carcinogens (US EPA, 2002). In Canada, the USA and some European countries regulation of soil contamination is based on developed soil quality criteria for selected PAHs or their sum. Only a few countries have established comprehensive soil guideline values for particular land use at least for the sum of priority PAHs $(\Sigma 7-16)$. Generally, the existing soil critical values provide only human health-riskbased approaches and do not consider protection of other ecological receptors. In turn, the US EPA has developed ecological soil screening levels (Eco-SSLs) for PAHs, which are derived separately for four groups of ecological receptors: plants, soil invertebrates, birds and animals. However, these screening levels are intended to evaluate an unacceptable ecological risk to terrestrial receptors; they are not designed to be used as clean-up levels. For this purpose the US EPA adopted the human-health-based preliminary remediation goals for soil using estimates of different routes of exposure. In contrast to this, the Russian Federation has not yet developed soil guideline values, at least for the sum of priority PAHs; normalization is provided only for soil contamination with benzo(a)pyrene without distinction for particular land use. Furthermore, no threshold values are provided for other POPs (polychlorinated biphenyls, chlororganic pesticides, benzene, toluene, ethylbenzene and xylenes). A summary of soil guideline values for PAHs set in some countries is presented in Table S1 in the Supplement. Thus, studies on soil contamination with PAHs are of the utmost importance as they provide information that can be further used to delineate special contaminated sites exhibiting a high risk of human exposure. Thousands of reports about PAH concentrations, sources and health risk assessments in urban and semiurban areas from all over the world were published in recent years (Yunker et al., 2002; Liu et al., 2010; Wang et al., 2013). Elevated levels of PAHs in urban soils were reported in Houston, USA (Hwang et al., 2002); Beijing, China (Tang et al., 2005); Glasgow, UK; Turin, Italy (Morillo et al., 2007); and Esbjerg, Denmark (Essumang et al., 2011).

St. Petersburg is the largest industrial and transport centre in the north-western region of Russia and is of great interest from the viewpoint of environmental concern. The eco- logical status of such a large centre reflects the whole range of socioeconomic problems resulting in the decline of human health under the influence of various chemical, physical and biological factors. The ecological situation in the city is determined by the emissions from more than a thousand industrial enterprises, a large railway junction, a seaport and the large motor vehicle fleet -1670794 cars and 207975 trucks as of 2014 (Belousova et al., 2015). All this transport is served by a huge number of petrol stations and transport companies: currently in St. Petersburg there are 27 fuel operators and 397 petrol stations. Industrial enterprises of the city include high-capacity, resource- and power-consuming ecologically dangerous works. According to the data collected from the automatic air monitoring system of the city in 2014, total emissions into the air from both the stationary sources and vehicles has reached $513200 \mathrm{t}$ of chemicals in 2014, including $16903 \mathrm{t}$ of hydrocarbons $\left(\mathrm{CH}_{x}\right), 3000 \mathrm{t}$ of black carbon (BC) and $47900 \mathrm{t}$ of volatile organic compounds (VOCs) (Belousova et al., 2015). The amount of emissions per capita is $135.9 \mathrm{~kg} \mathrm{yr}^{-1}$, per unit area $-434.5 \mathrm{t} \mathrm{km}^{-2}$ (Belousova et al., 2015). At the same time, $91.9 \%$ of emissions are attributed to transport activity. Industrial and transport emissions along with inputs from petroleum products are the major source of soil contamination with PAHs in urban areas. No systematic survey of soil contamination with priority PAHs has been conducted yet in St. Petersburg except for benzo(a)pyrene (Gorky and Petrova, 2012). Considering this fact and environmental aspects of the territory described above, St. Petersburg affords an excellent location to study geochemical cycles of PAHs.

Therefore, this study aims to test the hypothesis on the PAH load differences among urban territories with different land use scenarios. The results of this study would contribute to the knowledge about PAH distribution in urban soils of the Eastern European region and may be used by decision makers during land management.

Objectives of the study were to (1) explore qualitative and quantitative composition of 15 priority PAHs in urban soils in some parkland, residential and industrial areas of St. Petersburg; (2) compare with existing data on the PAH distribution in urban soils; (3) distinguish between PAH sources using PAH molecular ratios; and (4) evaluate cancer risks (CRs) associated with soil contamination with PAHs within selected areas.

\section{Materials and methods}

\subsection{Study site description}

Choice of the study area, namely the Primorsky, Vasileostrovsky and Kirovsky administrative districts of St. Petersburg, was made in the order of increasing location density of potential stationary sources of contamination with PAHs, population density and traffic activity. Detailed characteristics 
Table 1. Description of the study area.

\begin{tabular}{|c|c|c|c|c|}
\hline Characteristics & Units & $\begin{array}{r}\text { Primorsky } \\
\text { District }\end{array}$ & $\begin{array}{r}\text { Vasileostrovsky } \\
\text { District }\end{array}$ & $\begin{array}{r}\text { Kirovsky } \\
\text { District }\end{array}$ \\
\hline$S$ & $\mathrm{~km}^{2}$ & 109.87 & 17.1 & 47.10 \\
\hline Population & - & 534646 & 211048 & 334746 \\
\hline Industries & units & 250 & 350 & 70 \\
\hline Number of potential contamination sources with petroleum products & units & 14 & 7 & 10 \\
\hline Density of potential contamination sources & units per $\mathrm{km}^{2}$ & 0.13 & 0.41 & 0.21 \\
\hline $\mathrm{CH}_{x}$ emissions from stationary sources in 2014 & thousand tons & 0.556 & 0.034 & 0.708 \\
\hline VOC emissions from stationary sources in 2014 & thousand tons & 0.153 & 0.099 & 0.545 \\
\hline BC emissions from stationary sources in 2014 & thousand tons & 0.237 & 0.037 & 0.174 \\
\hline
\end{tabular}

about each chosen area are given in Table 1. Certain recreational, residential and industrial land use scenarios within each chosen district were included in the study. Information on the land use scenario of each chosen area was obtained using the online map service "Regional Geoinformation System (RGIS)" developed with the support of the committee for land resources and land management of St. Petersburg (Fig. 1). Potential sources of PAH contamination affecting PAH levels in soil here are high traffic activity (western highway and Primorsky prospect), steel and chemical industries (Kirovsky engineering plant, Baltic Shipyard plant, varnish factory Kronos SPb, and thermal power stations (North-West Thermal Power Plant).

Climate is moderately continental and significantly affected by the Baltic Sea. Annual amount of atmospheric precipitates varies from 565 to $635 \mathrm{~mm}$. The territory represents an almost flat plain with altitudes below $20 \mathrm{~m}$ above the sea level (Neva lowland). Natural soil formation usually occurs on ancient lake-marine littoral sands, sandy loams and loams (less) depleted in calcium (Gagarina et al., 2008). Urban soils are formed on the bulk deposits ranging from 0.9 to $4 \mathrm{~m}$ of thickness (Dashko et al., 2011). Soils are strongly disturbed by anthropogenic activities (buried, sealed and/or contaminated), with small relatively intact islands in natural and seminatural areas to the north, north-west and northeast of the city. An example of natural soils in St. Petersburg are Albeluvisols, which are widespread in suburb territories of the Leningradsky region. Soils of the historical centre are presented by anthropogenic soil-like formations called urbanozems (Stroganova et al., 1992) or urbiquazizems (Shishov et al., 2004) in national soil classification systems and generally characterized by light grain size and modified soil profiles, with abundant inclusions of anthropogenic artefacts in the form of debris, domestic wastes and remains of communications. They also have a neutral to alkaline $\mathrm{pH}$; high humus, nitrogen and phosphorus content; humate and fulvic-humate types of humus; and traces of chemical contamination (Rusakov et al., 2005; Matinyan et al., 2005; Ufimtseva et al., 2011). Investigated urban soils were classified as Technosols according to the World Reference Base for Soil Resources (Michéli et al., 2006).

\subsection{Sampling strategy and procedure}

Sampling was conducted in September 2013 at nine urban sites in dry and clear weather conditions according to international standard protocol ISO 10381-1 (2002) and national sampling standard GOST 17.4.4.02-84 (1984). Soil samples were taken from the 0 to $20 \mathrm{~cm}$ topsoil layer. A total of 135 grab soil samples were collected diagonally from $25 \mathrm{~m}^{2}$ sampling plots. Single samples were combined into 27 composite samples of $0.7 \mathrm{~kg}$ each. Location of the sampling sites was defined according to proximity to residential areas and potential pollution sources (Fig. 1a, b, c).

Sampling strategy responds to the study objectives and is aimed at providing comprehensive characterization of the selected sites suspected to be contaminated with PAHs.

Quantity of sampling sites ranged between two and five per each zone. The description of sampling sites providing information on location, proximity to potential sources of contamination, population density, road traffic and dominating wind direction is given in Table S3 in the Supplement. All the sampling plots were located near highways with different traffic rates with a distance of no further than $200 \mathrm{~m}$. Distance among sampling plots ranged between 100 and $200 \mathrm{~m}$. Total quantity of sampling plots was 34 . The sampling depth was common among all sites and matched a topsoil layer of $0-20 \mathrm{~cm}$. Depth of sampling is a function of exposure routes (e.g., soil ingestion, dermal contact with soil and dust, inhalation of contaminated dust, inhalation of volatile compounds). Five single initial samples of $0.05 \mathrm{~kg}$ each collected diagonally from $25 \mathrm{~m}^{2}$ sampling plots were combined into one grab sample of $0.1-0.2 \mathrm{~kg}$, packed in a dark glass flask, marked, transported to the laboratory and stored at $+4{ }^{\circ} \mathrm{C}$. A total of 135 grab soil samples were collected. Grab samples were combined into 27 composite samples of $0.7 \mathrm{~kg}$ each. The sampling scheme represents both the purposive and judgment sampling techniques, delineating sample locations that were assumed to be representative of the whole site and most contaminated. Instruments for sample deriva- 

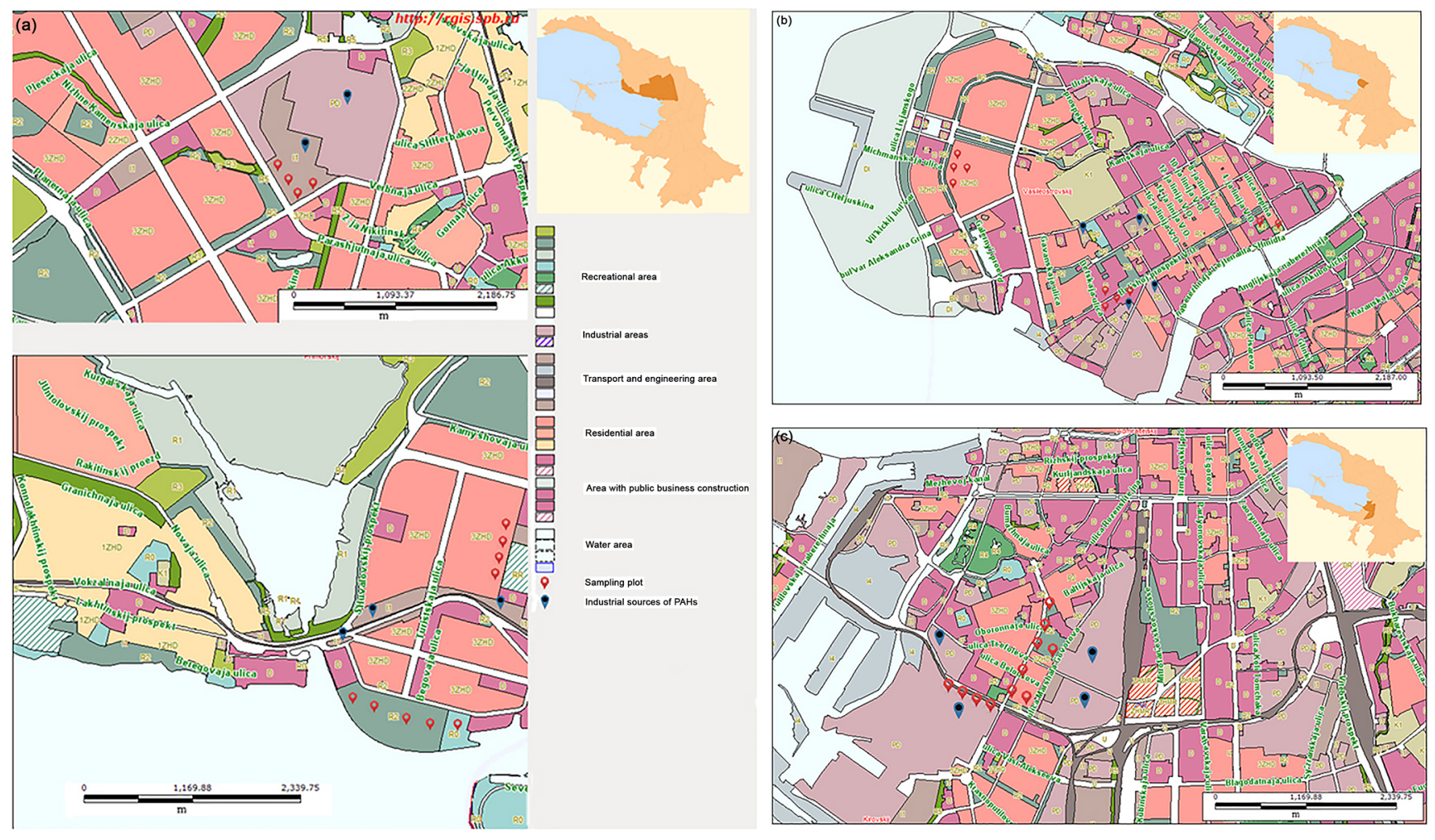

Figure 1. Location of the sampling sites.

tion included a stainless steel scoop and knife prewashed with acetone. The representativeness of collected samples was provided through mixing and taking an average sample using a quartering method.

Collected samples were packed in labelled sterile plastic bags, kept in cool conditions and transported to the laboratory. Once in the laboratory, soil samples were dispersed on the sterile glass plates and air-dried at room temperature for 5 days. Then they were cleaned of the organic and inorganic debris, ground in a laboratory vibrating cup mill, sieved through a $0.25 \mathrm{~mm}$ caprone sieve and finally stored in the dark glass containers prewashed with acetone until analysis. This technique enables the prevention of crosscontamination as well as losses of PAHs due to environmental factors (Berset et al., 1999).

\subsection{HPLC, PAH source identification and risk evaluation}

A total of 15 PAHs were analysed, including naphthalene (NAP), acenaphthene (ANA), fluorene (FLU), phenanthrene (PHE), anthracene (ANT), fluoranthene (FLT), pyrene (PYR), benzo(a)anthracene (BaA), chrysene (CHR), benzo(b)fluoranthene (BbF), benzo(k)fluoranthene (BkF), benzo(a)pyrene (BaP), dibenz(ah)anthracene(DBA), benzo(g,h,i)perylene (BPE) and indeno(1,2,3-cd)pyrene (IPY).
PAH content in samples was determined on the basis of US EPA method 8310 (1996a), national standard method PND F 16.1:2:2.2:3.62-09 (2009), and the method of Gabov (2007, 2008). Extraction of the PAHs was carried out at room temperature with methylene chloride (high purity grade) and ultrasonic treatment via a Branson 5510 ultrasonic bath (USA, power $469 \mathrm{~W}$, working frequency $42 \mathrm{kHz}$ ) following the US EPA method 3550b (1996b). Solvent removal (evaporation) was carried out with Kuderna-Danish concentrator (Supelco). PAH fractions were purified by consecutive chromatography in columns filled with aluminum oxide (Brockmann activity grade $2-3$, Neva Reaktiv) and silica gel (Fluka) according to the US EPA purification method 3660c (1996c). The purity was controlled by the absence of peaks in the blank chromatogram. A standard mixture of 15 PAHs (Supelco) with the concentrations of each component in the range of $100-2000 \mathrm{\mu g} \mathrm{cm}^{-3}$ was used to prepare the standard PAH solutions. Qualitative and quantitative determination of PAHs in soils was carried out with reverse-phase high-performance liquid chromatography (HPLC) in gradient mode with spectrofluorometric detection via the "LYuMAHROM" chromatograph (Lumex, Russia). Chromatography was performed at $30^{\circ} \mathrm{C}$ on a column Supelcosil ${ }^{\mathrm{TM}}$ LC-PAH n5 $\mu \mathrm{m}(25 \mathrm{~cm} \times 2.1 \mathrm{~mm})$. The mobile phase was provided with an acetonitrile-water gradient. Samples of $10 \mu \mathrm{L}$ volume were injected using the injection 
valve. Individual PAHs were identified by the time of retention and comparison of fluorescence spectra of the components coming from the column with spectra of the standard PAHs. Quantitative analysis of PAHs was performed using an external standard method. For the quality assurance purposes Standard Reference Materials ${ }^{\circledR} 1944$ New York/New Jersey waterway sediment (National Institute of Standards and Technologies (NIST), USA) containing a mixture of 15 PAHs was subjected to the procedure described above. The error of measuring the PAHs (benz[a]pyrene) in the soils was $35 \%$ in the range of $5-40 \mathrm{ng} \mathrm{g}^{-1}$ and $25 \%$ in the range of 40-2000 $\mathrm{ng} \mathrm{g}^{-1}$ with a confidence probability of $P=0.95$.

PAH molecular markers and ratios were used to determine PAH sources (Yunker et al., 2002; Hwang et al., 2003; Wang et. al 2015, 2017). The sum of combustion PAHs (combPAH/15PAH) was used as the tracer of pyrogenic sources. The combPAH/15PAH marker indicates the portion of the sum of combustion-specific compounds in total PAH content, which are fluoranthene, pyrene, chrysene, benzo(a)anthracene, benzo(k)fluoranthene, benzo(b)fluoranthene, benzo(a)pyrene, benzo(g,h,i)perylene and indeno(1,2,3-cd)pyrene (Prahl and Carpenter, 1983). Applied PAH molecular markers and ratios as well as their ranges are given in Table $\mathrm{S} 2$ in the Supplement.

Since $\mathrm{BaP}$ is the most studied $\mathrm{PAH}$, the carcinogenic potential of other PAHs is generally assessed referring it to that of BaP (toxicity equivalence factors, TEFs; in a similar way to the toxic equivalents (TEQs) used in the evaluation of the toxicity of dioxins and furans. The benzo[a]pyrene potency equivalence approach is a major approach used by the US EPA (1993, 1999), California EPA (OEHHA, 1992), Netherlands (Verbruggen et al., 2001), UK (Duggan and Strehlow, 1995) or provinces of British Columbia and Ontario, for example, for assessing the human health risks of PAH-containing mixtures.

Site-specific incremental lifetime CR was calculated in derived soil samples taken from areas with different land uses by application of the risk exposure model for chemicals of the Risk Assessment Information System (RAIS). This calculation estimates a theoretical excess CR expressed as the proportion of a population that may be affected by a carcinogen during a lifetime of exposure. The CRs via ingestion, dermal contact and inhalation of soil particles as well total CR were estimated using the following Eqs. (1), (2) and (3) (US EPA, 2004):

$\mathrm{CR}_{\text {ing }}=\frac{C_{\text {soil }} \times \mathrm{IR}_{\text {soil }} \times \mathrm{EF} \times \mathrm{ED} \times \mathrm{CF}}{\mathrm{BW} \times \mathrm{AT}} \times \mathrm{CSF}_{\mathrm{o}}$,

where $\mathrm{CR}_{\text {ing }}$ is the cancer risk (unitless) through ingestion of soil particles. $C_{\text {soil }}$ is the total $\mathrm{BaP}_{\text {eq }}$ concentrations of soil PAHs; $\mathrm{IR}_{\text {soil }}$ is the soil ingestion rate $\left(\mathrm{mg} \mathrm{d}^{-1}\right)$; EF is the exposure frequency $\left(\mathrm{d} \mathrm{yr}^{-1}\right)$; ED is the exposure duration (years); $\mathrm{CF}$ is the conversion factor of $10^{-6} \mathrm{mg} \mathrm{kg}^{-1}$; $\mathrm{BW}$ is body weight $(\mathrm{kg})$; AT is the average life span (d); $\mathrm{CSF}_{\mathrm{o}}$ is oral (ingestion) cancer slope factor $\left(\left(\mathrm{mg} \mathrm{kg}^{-1} \mathrm{~d}^{-1}\right)^{-1}\right)$; $\mathrm{CSF}_{\mathrm{o}}=7.3\left(\mathrm{mg} \mathrm{kg}^{-1} \mathrm{~d}^{-1}\right)^{-1}$, for BaP (US EPA, 2004).

$$
\begin{aligned}
\mathrm{CR}_{\text {derm }} & =\frac{C_{\text {soil }} \times \mathrm{SA} \times \mathrm{AF}_{\text {soil }} \times \mathrm{ABS} \times \mathrm{EF} \times \mathrm{ED} \times \mathrm{CF}}{\mathrm{BW} \times \mathrm{AT}} \\
& \times \frac{\mathrm{CSF}_{\mathrm{o}}}{\mathrm{GIABS}^{2}}
\end{aligned}
$$

where $\mathrm{CR}_{\text {derm }}$ is the cancer risk (unitless) for the dermal contact pathway, SA is the exposed surface area of the skin $\left(\mathrm{cm}^{2}\right), \mathrm{AF}_{\text {soil }}$ is the dermal adherence factor $\left(\mathrm{mg} \mathrm{cm}^{-2}\right), \mathrm{ABS}$ is the absorption factor (unitless) and GIABS is the fraction of contaminant absorbed in the gastrointestinal tract (unitless).

$\mathrm{CR}_{\text {inh }}=\frac{C_{\text {soil }} \times \mathrm{IR}_{\text {air }} \times \mathrm{EF} \times \mathrm{ED}}{\mathrm{PEF} \times \mathrm{BW} \times \mathrm{AT}} \times \mathrm{CSF}_{\mathrm{i}}$,

where $\mathrm{CR}_{\mathrm{inh}}$ is the cancer risk (unitless) for the inhalation pathway. $I_{\text {air }}$ is the inhalation rate $\left(\mathrm{m}^{3} \mathrm{~d}^{-1}\right), \mathrm{CSF}_{\mathrm{i}}$ is the inhalation cancer slope factor $\left(\left(\mathrm{mg} \mathrm{kg}^{-1} \mathrm{~d}^{-1}\right)^{-1}\right)$ and $\mathrm{CSF}_{\mathrm{i}}$ is obtained from the inhalation unit risk (IUR, $\left(\mu \mathrm{g} \mathrm{m}^{-3}\right)^{-1}$ ) of $\mathrm{BaP}$ according to the recommended method by the US EPA (2013). PEF is the soil particle emission factor $\left(\mathrm{m}^{3} \mathrm{~kg}^{-1}\right)$. The total incremental lifetime carcinogenic risk (TILCR) was calculated by summing the CRs for children and adults. Evaluation of CRs in industrial areas was provided only for adults (composite workers) as the dominating group of population. Due to differences in activities, physiology (body weight, skin surface, lung volume) and habits, adults and children are exposed to PAHs through different routes and on different scales. For example, children are less vulnerable to dermal contact with dust and ash particles containing PAHs due to the smaller skin surface, which leads to smaller CRs (Wang et al., 2015). This paper provides results of CR evaluation only for the sum of adults and children without separation for individual groups.

\subsection{Soil property analysis and statistical treatment}

Total organic carbon (TOC) was determined using a Leco CHN628 elemental analyser (USA, combustion temperature $1030^{\circ} \mathrm{C}$, oxygen boost time $28 \mathrm{~s}$ ). Inorganic carbonates were removed before analysis by in situ acidification of the ground samples with $1 \mathrm{M}$ hydrochloric acid in order to avoid uncertainty in TOC determination. Clay content was determined with a Shimadzu SALD-2201 laser diffractometer (Japan). All measurements were carried out in triplicate. All measurements were converted to an absolutely dry sample.

Statistical treatment of the data was carried out with STATISTICA 10.0 software. One-way ANOVA was applied in order to test statistical significance of differences among obtained data. The essence of the method is based on estimation of the significance of the average differences among three or 
more independent groups of data combined by one feature (factor). The null hypothesis of the average equality is tested during the analysis, suggesting the provisions on the equality or inequality of variances. In case of rejection of the null hypothesis, basic analysis is not applicable. If the variances are equal, the $f$-test Fisher criterion is used for evaluation of intergroup and intergroup variability. If $f$ statistics exceed the critical value, the null hypothesis is rejected considering inequality of averages. A post hoc test (Fisher's least significant difference) was used to provide detailed evaluation of average differences among analysed groups of data. A feature of the post hoc test is application of intra-group mean squares for the assessment of any pair averages. Differences were considered to be significant at the $95 \%$ confidence level. All calculations were carried out via STATISTICA 10.0 software. PAH concentrations were analysed at least in triplicate. Calculated mean concentrations were provided with standard deviations $(a \pm b)$.

\section{Results and discussion}

\subsection{PAH concentrations in studied soils}

Data on analysed properties of the studied soils are presented in Table 2. Measured TOC concentrations in studied samples ranged between 3.82 and $6.41 \%$ with a median value of $4.80 \%$. Numerous studies suggested that soil organic matter (SOM) content plays an important role in retention of PAH in soil (Chung and Alexander, 2002). In simple terms, the higher SOM concentrations are, then the higher the amount of PAH that can be absorbed (Wilcke, 2000). Entering the soil from the atmosphere, PAHs are preferentially sorbed to aggregate surfaces (Wilcke, 1996). The close association of PAHs with SOM results in differentiation of organic contaminant pools among particle size fractions (Guggenberger et al., 1996). A significant increase in PAH concentrations in finer fractions is shown in a number of studies (Wilcke, 1996). Clay content in studied soils ranges between 1.87 and $8.50 \%$. Correlation coefficients were calculated in the present study in order to reveal the relationship between levels of PAH in soil and analysed soil parameters. A strong positive correlation was found between the sum of $15 \mathrm{PAH}$ in soil and clay content $(r=0.91 ; n=27 ; p=0.95)$; however, no correlation of total PAH and TOC concentrations in soil was detected.

The levels of 15 individual PAH compounds analysed in soils are shown in Table 3. The sum of 15 PAHs and the sum of seven compounds included in the group of probable human carcinogens (B2) by the US EPA (1993) are additionally given. Total PAH concentrations in studied soils were found to range from traces to $8.06 \mathrm{mg} \mathrm{kg}^{-1}$ (sum of 15 priority PAHs, hereafter referred to as $15 \mathrm{PAH}$ ). The vast majority of samples were characterized by concentrations of more than $1 \mathrm{mg} \mathrm{kg}^{-1}$, which is set as a guide level for to- tal PAH content in soil by a number of countries. The highest 15 PAH levels were observed in soil samples collected from residential and industrial sites, reaching an average of 4.19 and $4.01 \mathrm{mg} \mathrm{kg}^{-1}$, respectively, with a maximal value of $8.06 \mathrm{mg} \mathrm{kg}^{-1}$ for an industrial site in Kirovsky district (hereafter - K.D.) Concentrations found in parkland areas were substantially lower than those of residential and industrial areas, with an average value of $1.08 \mathrm{mg} \mathrm{kg}^{-1}$.

Distribution of the sum of the seven carcinogenic PAHs (7 PAH) in soils of the studied urban sites is generally characterized by the same pattern as the total PAH content in soils. The highest 7 PAH levels were measured in soil samples taken from residential sites $\left(1.94 \mathrm{mg} \mathrm{kg}^{-1}\right)$, with an absolute value of $3.47 \mathrm{mg} \mathrm{kg}^{-1}$ in Technosol of a K.D. residential area. The 7 PAH levels in parkland areas corresponds to the distribution of $15 \mathrm{PAH}$. All sampling sites were located in a proximity of less than $250 \mathrm{~m}$ to the highways (Korablestroiteley street, Stachek prospect, Optikov prospect, university embankment, Bolshoi prospect in Vasilievsky Ostrov and others) showing heavy traffic. The portion of 7 PAH to the $15 \mathrm{PAH}$ in all tested samples ranged between 41 and $46 \%$, which evidently shows that the soils may represent a considerable health risk for humans.

The sum of PAHs is mostly dominated by heavymolecular-weight PAHs with four to five rings. The portion of four-ringed PAH compounds in the soils of residential and industrial sites accounts for $50 \%$ of the sum, decreasing to $34 \%$ in parkland soils. Five-ringed PAHs including such compounds as $\mathrm{BaP}, \mathrm{BbF}, \mathrm{BkF}$ and DBA contribute up to $31 \%$ of the sum of PAH, insignificantly varying among studied areas. The rest is accounted for by the six-ringed (10-14\%) and low-molecular-weight PAHs with two or three rings in structure $(11-17 \%)$.

The pie chart illustrating composition of PAH mixtures in soils is depicted in Fig. 2. The obvious equality in PAH distribution patterns in all studied sites clearly indicates the common source of PAHs. Pyrene and fluoranthene (four-ring PAHs) are the most abundant compounds in the examined samples, and account for $16-18 \%$ of 15 PAH. The following predominant compounds are five-ring PAHs benzo(b)fluoranthene (10-11\%) and benzo(a)pyrene $(8-11 \%)$. The rest is represented by lighter-weight PAHs (two- to three-ring PAHs) and is generally dominated by phenanthrene $(6-9 \%)$. Domination of four- and five-ring PAHs, mainly PYR, FLT, BbF and BaP, in studied soils is indicative of elevated diesel fuel consumption activity in the area. Estimated diesel consumption in St. Petersburg reaches $38 \%$ of the total fuel use for transportation (Belousova et al., 2015). As is known, the emission rate of heavyweight PAH fraction during diesel combustion is several times higher than that during gasoline combustion (Marr et al., 1999).

The data obtained are nearly consistent with data from Lodygin et al. (2008) exploring PAH levels (sum of 11 PAHs) in soils of Vasil'yevskiy Island in St. Petersburg). The main anthropogenic impact on soils of residential areas of the is- 
Table 2. Physicochemical properties of the studied soils.

\begin{tabular}{|c|c|c|c|c|c|c|c|c|}
\hline \multirow[t]{2}{*}{ District } & \multirow[t]{2}{*}{ Land use } & \multirow{2}{*}{$\begin{array}{l}\text { Soil name } \\
\text { (WRB) }\end{array}$} & \multirow{2}{*}{\multicolumn{2}{|c|}{$\begin{array}{l}\text { Munsell colour } \\
\text { chart index }\end{array}$}} & TOC & $N_{\text {tot }}$ & Clay & \multirow[t]{2}{*}{$\mathrm{pH}$} \\
\hline & & & & & & $\%$ & & \\
\hline \multirow{3}{*}{ Primorsky } & Parkland & Mollic Technosol & $2.5 \mathrm{YR}$ & $4 / 1$ & $4.10 \pm 0.01$ & $0.35 \pm 0.06$ & $5.83 \pm 0.21$ & 6.52 \\
\hline & Residential & Urbic Technosol & $2.5 \mathrm{YR}$ & $4 / 1$ & $3.82 \pm 0.03$ & $0.41 \pm 0.08$ & $7.43 \pm 0.06$ & 7.34 \\
\hline & Industrial & Urbic Technosol & $10 \mathrm{YR}$ & $4 / 1$ & $5.49 \pm 0.02$ & $0.23 \pm 0.04$ & $8.50 \pm 0.10$ & 7.15 \\
\hline \multirow{3}{*}{ Vasileostrovsky } & Parkland & Mollic Technosol & $2.5 \mathrm{YR}$ & $4 / 1$ & $5.39 \pm 0.01$ & $0.28 \pm 0.07$ & $7.3 \pm 0.20$ & 7.04 \\
\hline & Residential & Urbic Technosol & $2.5 \mathrm{YR}$ & $4 / 1$ & $6.41 \pm 0.02$ & $0.33 \pm 0.05$ & $1.87 \pm 0.12$ & 7.45 \\
\hline & Industrial & Urbic Technosol & $5 \mathrm{YR}$ & $7 / 1$ & $5.28 \pm 0.02$ & $0.29 \pm 0.06$ & $3.27 \pm 0.15$ & 7.76 \\
\hline \multirow{3}{*}{ Kirovsky } & Parkland & Mollic Technosol & $2.5 \mathrm{YR}$ & $4 / 1$ & $4.19 \pm 0.03$ & $0.32 \pm 0.09$ & $7.5 \pm 0.10$ & 6.84 \\
\hline & Residential & Urbic Technosol & $5 \mathrm{YR}$ & $7 / 1$ & $4.80 \pm 0.03$ & $0.30 \pm 0.05$ & $3.27 \pm 0.15$ & 7.12 \\
\hline & Industrial & Urbic Technosol & $5 \mathrm{YR}$ & $7 / 1$ & $3.09 \pm 0.02$ & $0.27 \pm 0.04$ & $7.67 \pm 0.06$ & 7.05 \\
\hline
\end{tabular}

Table 3. Mean PAH concentrations in soils of St. Petersburg $\left(\mathrm{mg} \mathrm{kg}^{-1}\right)$.

\begin{tabular}{|c|c|c|c|c|c|c|c|c|c|c|}
\hline \multirow[t]{2}{*}{ Compound } & \multicolumn{3}{|c|}{ Parkland $(n=9)$} & \multicolumn{3}{|c|}{ Residential $(n=9)$} & \multicolumn{3}{|c|}{ Industrial $(n=9)$} & \multirow{2}{*}{$\begin{array}{r}P \text { One-way } \\
\text { ANOVA } \\
(\alpha=0.05)\end{array}$} \\
\hline & Mean \pm SD & Max & Min & Mean \pm SD & Max & Min & Mean \pm SD & Max & Min & \\
\hline NAP & $0.06 \pm 0.08$ & 0.28 & 0.03 & $0.05 \pm 0.02$ & 0.07 & 0.00 & $0.09 \pm 0.07$ & 0.21 & 0.00 & 0.42 \\
\hline ANA & $02 \pm 0.06$ & 0.18 & 0.00 & 0.00 & 0.01 & 0.00 & 0.01 & 0.03 & 0.00 & - \\
\hline FLU & $.10 \pm 0.06$ & 0.23 & 0.05 & $0.17 \pm 0.11$ & 0.40 & 0.03 & $0.17 \pm 0.11$ & 0.31 & 0.06 & 0.04 \\
\hline PHE & $.16 \pm 0.13$ & 0.45 & 0.05 & $0.26 \pm 0.17$ & 0.47 & 0.03 & $0.36 \pm 0.22$ & 0.65 & 0.07 & 0.04 \\
\hline ANT & $.06 \pm 0.11$ & 0.37 & 0.01 & $0.04 \pm 0.04$ & 0.11 & 0.00 & $0.05 \pm 0.03$ & 0.09 & 0.01 & 0.87 \\
\hline FLT & $.18 \pm 0.07$ & & & $0.69 \pm 0.52$ & & 0.04 & $0.72 \pm 0.48$ & & & 0.02 \\
\hline PYR & $0.18 \pm 0.08$ & 0.35 & 0.09 & $0.74 \pm 0.55$ & 1.67 & 0.04 & $0.70 \pm 0.46$ & 1.50 & 0.16 & 0.02 \\
\hline $\mathrm{BaA}$ & $0.19 \pm 0.17$ & 0.53 & 0.04 & $0.35 \pm 0.26$ & 0.64 & 0.02 & $0.30 \pm 0.20$ & 0.67 & 0.07 & 0.05 \\
\hline CHR & $0.15 \pm 0.14$ & 0.44 & 0.01 & $0.31 \pm 0.24$ & 0.69 & 0.02 & $0.28 \pm 0.18$ & 0.54 & 0.07 & 0.05 \\
\hline $\mathrm{BbF}$ & $0.23 \pm 0.21$ & 0.69 & 0.05 & $0.46 \pm 0.30$ & 0.84 & 0.02 & $0.41 \pm 0.30$ & 1.00 & 0.10 & 0.04 \\
\hline $\mathrm{BkF}$ & $0.15 \pm 0.17$ & 0.56 & 0.02 & $0.19 \pm 0.14$ & 0.36 & 0.01 & $0.16 \pm 0.11$ & 0.33 & 0.04 & 0.82 \\
\hline $\mathrm{BaP}$ & $0.22 \pm 0.22$ & 0.70 & 0.04 & $0.43 \pm 0.32$ & 0.87 & 0.02 & $0.34 \pm 0.23$ & 0.73 & 0.07 & 0.04 \\
\hline DBA & $0.03 \pm 0.06$ & 0.18 & 0.00 & $0.02 \pm 0.01$ & 0.04 & 0.00 & $0.02 \pm 0.03$ & 0.08 & 0.00 & 0.93 \\
\hline BPE & $0.17 \pm 0.14$ & 0.46 & 0.04 & $0.29 \pm 0.21$ & 0.52 & 0.01 & $0.27 \pm 0.20$ & 0.69 & 0.06 & 0.05 \\
\hline IPY & $0.12 \pm 0.15$ & 0.49 & 0.00 & $0.17 \pm 0.17$ & 0.45 & 0.01 & $0.15 \pm 0.13$ & 0.38 & 0.00 & 0.76 \\
\hline$\sum 15 \mathrm{PAH}$ & $2.02 \pm 1.50$ & 4.78 & 0.58 & $4.17 \pm 2.91$ & 8.10 & 0.33 & $4.02 \pm 2.61$ & 8.06 & 0.86 & 0.04 \\
\hline$\sum 7$ PAH $^{*}$ & $1.08 \pm 1.04$ & 3.18 & 0.21 & $1.94 \pm 1.36$ & 3.47 & 0.10 & $1.66 \pm 1.13$ & 3.20 & 0.36 & 0.05 \\
\hline
\end{tabular}

NAP - naphthalene; ANA - acenaphthene; FLU - fluorene; PHE - phenanthrene; ANT - anthracene; FLT - fluoranthene; PYR - pyrene; BaA -

benzo(a)anthracene; CHR - chrysene; BbF - benzo(b)fluoranthene; BkF - benzo(k)fluoranthene; BaP - benzo(a)pyrene; DBA - dibenz(ah)anthracene; BPE - benzo(g,h,i)perylene; IPY - indeno(1,2,3-cd) pyrene.

* Carcinogenic PAHs: chrysene, benzo(a)anthracene, benzo(b)fluoranthene, benzo(k)fluoranthene, benzo(a)pyrene, indeno(1,2,3-cd) pyrene and dibenz(ah)anthracene.

land was exerted by light polyarens, including two- to fourring substances (as stated by the author), the portion of which in the total content of PAHs was more than $50 \%$. Maximum concentrations of PAHs were detected in soils along highways with intense traffic and considerable emissions of combustion gases. The reported total PAH content ranged from 0.197 to $8.20 \mathrm{mg} \mathrm{kg}^{-1}$ between different land utilization types. The described distribution patterns of individual PAHs are similar to those of this study: the most abundant are fourto five-ring PAHs, particularly pyrene (17\%), fluoranthene $(17 \%)$, benzo(g,h,i)perylene $(13 \%)$, benzo(b)fluoranthene
(12\%) and benzo(a)pyrene (12\%). Several samples were noticed to exhibit higher contents of heavy polyarens of natural origin, as both of the samples were represented by fresh organic material (peat), which is used as amendment in soils of residential areas and roadsides. Thus the findings of the above-mentioned study suggest that spatial distribution of PAHs is mainly dictated by the closeness to highways and by the artificial input of peat material in the urban soils.

There is still a lack of information about PAH concentrations in the soils of St. Petersburg; thus the data on the pollutant distribution in water sediments obtained from en- 


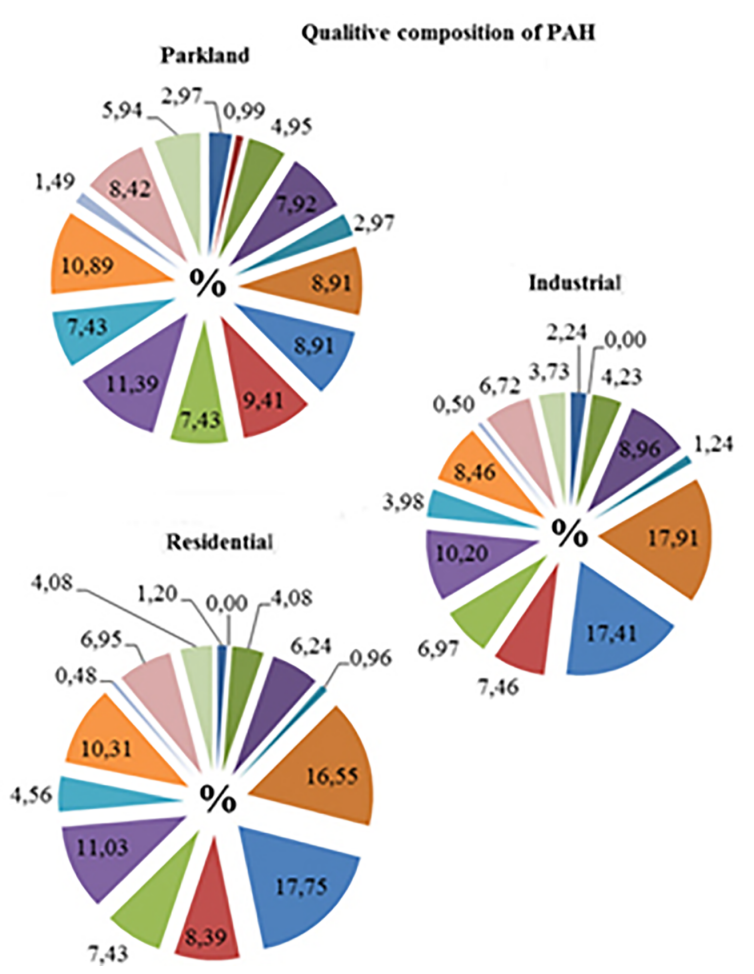

Figure 2. Composition of PAH mixtures in studied soil.

vironmental monitoring systems may be applied in discussion for evaluation of the PAH loads. Comparative PAH levels were detected in bottom sediments in different parts of Neva Bay (Gulf of Finland) and along the Niva River waterway. Reported total PAH concentrations ranged between 0.01 and $14.5 \mathrm{mg} \mathrm{kg}^{-1}$ (HELCOM, 2014). Benzo(a)pyrene was detected in $96 \%$ of sediment samples taken, with an average concentration of $0.09 \mathrm{mg} \mathrm{kg}^{-1}$.

Total PAH concentrations in soils of urban and industrial sites from a number of investigations set in other countries are summarized in Table 4. In general terms, the predominance of three- to five-ring PAHs is noted, which is mainly attributed to the influence of anthropogenic activities on the studied territories.

\subsection{Determination of the PAH sources and statistics}

While a domination of high-molecular-weight PAH fraction indicates a combustion origin (pyrogenic), enrichment of low-molecular-weight PAHs is common in fresh fuels (petrogenic) (Budzinski et al., 1997). Special molecular markers and ratios, proposed by Yunker et al. (2002), and a total combustion PAH index, reported by Hwang et al. (2003), were applied for PAH source apportionment. Obtained meanings of applied PAH molecular ratios are listed in Table 5. Applied markers allow us to distinguish between pyrogenic and petrogenic as well as traffic and non-traffic sources of PAHs, namely ANT / (ANT + PHE), FLT / (FLT + PYR),
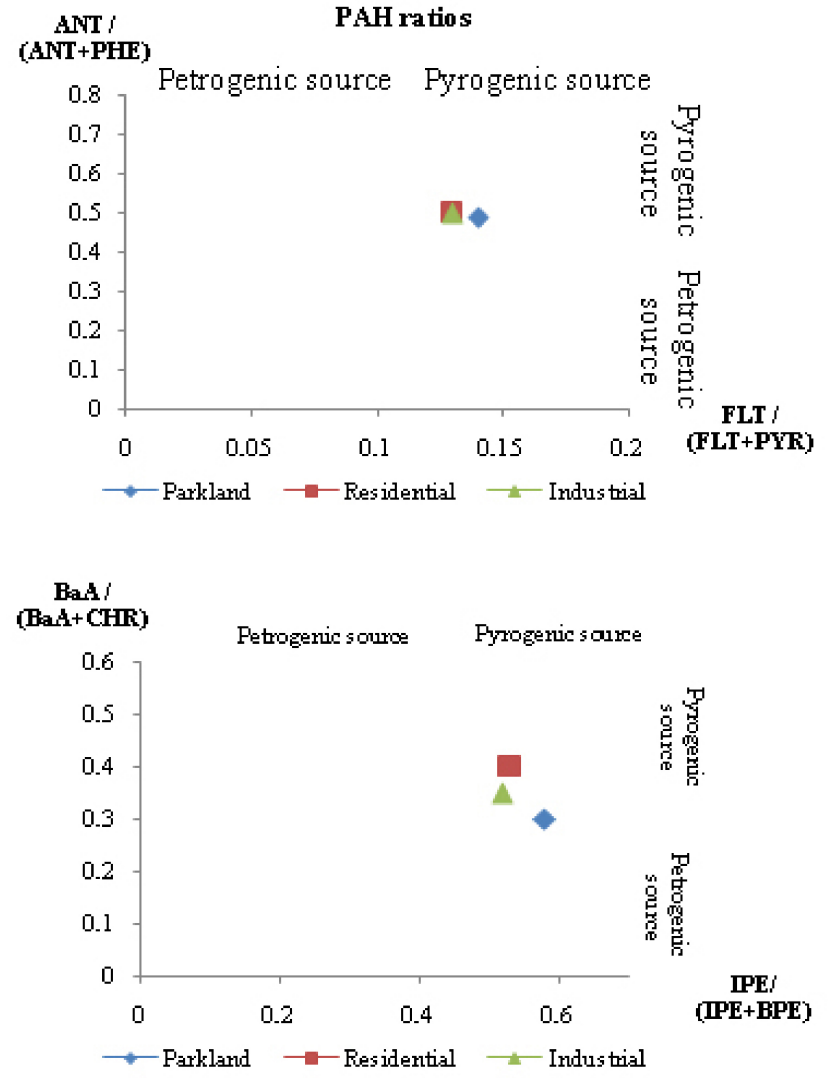

BaP/BPE

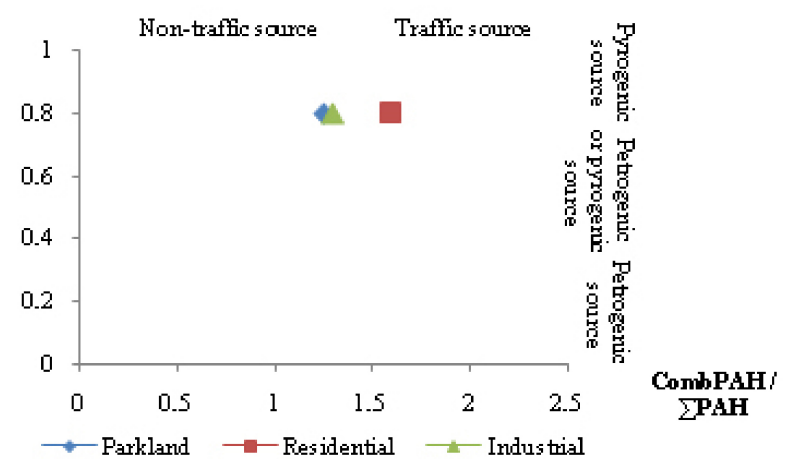

Figure 3. PAH source apportionment.

$\mathrm{BaA} /(\mathrm{BaA}+\mathrm{CHR}), \quad \mathrm{IPY} /(\mathrm{IPY}+\mathrm{BPE}), \quad \mathrm{CombPAH} /$ $15 \mathrm{PAH}$ and $\mathrm{BaP} / \mathrm{BPE}$. Calculated ratios for samples taken from residential and industrial areas exhibited numbers that point to a domination of pyrogenically formed PAHs. The cross plots of the PAH ratios are depicted in Fig. 3

Several markers are indicative of certain combustion sources of PAHs, pointing to gasoline, diesel, crude oil or grass, coal and wood combustion origins, namely $\mathrm{FLT} /(\mathrm{FLT}+\mathrm{PYR}), \mathrm{BaA} /(\mathrm{BaA}+\mathrm{CHR})$, $\mathrm{IPY} /(\mathrm{IPY}+\mathrm{BPE})$ and $\mathrm{BaP} / \mathrm{BPE}$. The calculated FLT / (FLT + PYR) (0.49-0.51), IPY / (IPY + BPE) $(0.30-$ 
Table 4. Reported total concentrations of PAHs in urban soils ( $\mathrm{mg} \mathrm{kg}^{-1}$ dry weight) from a number of studies.

\begin{tabular}{|c|c|c|c|c|}
\hline Location & Study area & $\begin{array}{l}\text { Concentrations } \\
\qquad\left(\mathrm{mg} \mathrm{kg}^{-1} \text { d.w. }\right)\end{array}$ & $\sum \mathrm{PAH}$ & Reference \\
\hline Houston, TX, USA & Urban/suburban & $0.2-2.2$ & 23 & Hwang et al. (2002) \\
\hline Mexico City, Mexico & Urban/industrial & $0.20-1.10$ & 17 & Hwang et al. (2003) \\
\hline Beijing, China & Urban & $0.22-27.82$ & 16 & Tang et al. (2005) \\
\hline New Orleans, USA & Urban & 3.73 (median) & 16 & Mielke et al. (2001) \\
\hline $\begin{array}{l}\text { Tarragona County, } \\
\text { Catalonia, Spain }\end{array}$ & $\begin{array}{l}\text { Urban/residential/ } \\
\text { industrial }\end{array}$ & $0.11-1.00$ & 16 & Nadal et al. (2004) \\
\hline $\begin{array}{l}\text { Swiss soil monitoring } \\
\text { system (NABO), Switzerland }\end{array}$ & $\begin{array}{l}\text { Urban parkland/ } \\
\text { semiurban }\end{array}$ & $0.05-0.62$ & 16 & Bucheli et al. (2004) \\
\hline Tallinn, Estonia & Urban & $2.20 \pm 1.40$ & 12 & Trapido (1999) \\
\hline Linz, Austria & Industrial & 1.45 (median) & 18 & Weiss et al. (1994) \\
\hline Tokushima, Japan & Urban & 0.61 & 13 & Yang et al. (2002) \\
\hline Shanghai, China & Main urban & $0.13-8.65 / 0.08-7.22$ & $26 / 16$ & Wang et al. (2013) \\
\hline El-Tebbin, Egypt & Urban/industrial & $0.05-5.56$ & 16 & Havelcová et al. (2014) \\
\hline Phoenix, Arizona, USA & Urban (highways) & $0.06-10.12$ & 20 & Marusenko et al. (2011) \\
\hline
\end{tabular}

Table 5. PAH ratios in studied soils.

\begin{tabular}{|c|c|c|c|c|c|c|}
\hline Ratio & Parkland & $\begin{array}{l}\text { Indicated source } \\
\text { (origin) }\end{array}$ & Residential & $\begin{array}{l}\text { Indicated source } \\
\text { (origin) }\end{array}$ & Industrial & $\begin{array}{l}\text { Indicated source } \\
\text { (origin) }\end{array}$ \\
\hline $\mathrm{ANT} /(\mathrm{ANT}+\mathrm{PHE})$ & 0.19 & Pyrogenic & 0.09 & Petrogenic & 0.12 & Pyrogenic \\
\hline FLT / (FLT + PYR) & 0.51 & $\begin{array}{l}\text { Grass; coal and } \\
\text { wood combustion }\end{array}$ & 0.49 & $\begin{array}{l}\text { Gasoline, diesel and } \\
\text { crude oil combustion }\end{array}$ & 0.50 & $\begin{array}{l}\text { Gasoline, diesel and } \\
\text { crude oil combustion }\end{array}$ \\
\hline $\mathrm{BaA} /(\mathrm{BaA}+\mathrm{CHR})$ & 0.58 & $\begin{array}{l}\text { Grass; coal and } \\
\text { wood combustion }\end{array}$ & 0.52 & $\begin{array}{l}\text { Grass; coal and } \\
\text { wood combustion }\end{array}$ & 0.51 & $\begin{array}{l}\text { Grass; coal and } \\
\text { wood combustion }\end{array}$ \\
\hline IPY / (IPY + BPE) & 0.30 & $\begin{array}{l}\text { Liquid fossil } \\
\text { fuel combustion }\end{array}$ & 0.40 & $\begin{array}{l}\text { Liquid fossil } \\
\text { fuel combustion }\end{array}$ & 0.34 & $\begin{array}{l}\text { Liquid fossil } \\
\text { fuel combustion }\end{array}$ \\
\hline $\mathrm{BaP} / \mathrm{BPE}$ & 1.20 & Traffic sources & 1.64 & Traffic sources & 1.31 & Traffic sources \\
\hline CombPAH / $\sum$ PAH & 0.79 & $\begin{array}{l}\text { Combustion- } \\
\text { dominated source }\end{array}$ & 0.80 & $\begin{array}{l}\text { Combustion- } \\
\text { dominated source }\end{array}$ & 0.81 & $\begin{array}{l}\text { Combustion- } \\
\text { dominated source }\end{array}$ \\
\hline
\end{tabular}

$40)$ and $\mathrm{BaP} / \mathrm{BPE}(1.20-1.64)$ values point to a domination of gasoline, diesel and oil combustion. However, obtained values of FLT / (FLT + PYR ) and $\mathrm{BaA} /(\mathrm{BaA}+\mathrm{CHR})$ ratios suggested that coal and wood combustion have a certain role in PAH origination as well. It is important to note that the shift of heavy- and low-molecular-weight PAH ratios towards the heavy ones cannot be explained by only the anthropogenic factor, the degradation of lighter PAHs due to environmental factors such as photolysis under direct sun rays in the topsoil layers or thermal degradation; biological uptake and biodegradation may play a significant role as well (Wild and Jones, 1995; Johnsen, 2005; Choi et al., 2010). These processes are predetermined by physical and chemical properties of the lighter fraction PAHs such as low molecular weight, high vapour pressure and high volatility rate (Mackay and Hickie, 2000). Volatilization proved to play the most significant role in the global degradation of the two- and three-ringed PAHs especially. Park et al. (1990) reported that approximately $30 \%$ loss of naphthalene accounts for volatilization, while for the remaining compounds this process was insignificant. Heavy-weight PAHs, i.e., four- to six-ring compounds, have low solubility in water, low volatility, and a strong affinity to particulates (BC and SOM, fine fractions) and are less accessible for biological uptake and degradation and thus are more persistent in the environment (Johnsen, 2005; Haritash, 2009). It has been proven that PAHs may form non-extractable $\left[{ }^{14} \mathrm{C}\right] \mathrm{PAH}$ residues in soil under the stimulation of microbial activity, which obviously leads to unexpectedly lower results while analyzing the concentrations of naphthalene, anthracene, pyrene and benzo(a)pyrene in soil samples (Eschenbach et al., 1998).

Obtained probabilities for one-way ANOVA revealed no statistically significant differences of total PAH concentrations in soils among different land uses $(P<0.05)$. Probabilities for ANOVA are given in Table 3.

The differences in levels of individual PAH compounds were tested using a post hoc Fisher's least significant difference test. The results showed significant differences of FLU, PHE, FLT, PYR, BaA, CHR, BbF, BaP and BPE con- 
centrations among parkland, residential and industrial areas $(p=0.02-0.05)$. The tested hypothesis suggested that PAH levels in urban soil may differ among areas with different land utilization types, in the following order: industrial, residential, parkland. The results of the study proved the argument of the influence of the land use factor on the difference of PAH levels in urban soils between studied sites. The land use factor is intensively expressed in distribution of the dominant individual PAHs, particularly BaP, PHE, FLT and PYR. These compounds are known to be a part of the PAH mixtures isolated from the exhaust gases and industrial emissions (Rehwagen et al., 2005) Thus it is not too surprising that elevated levels of these pollutants are expected primarily in industrial and transport areas along with surrounding areas, where maximum input of $\mathrm{BC}$ from air pollution sources is noted. PHE representing low-molecular-weight PAH is a thermodynamically stable tri-aromatic compound arising from petroleum-hydrocarbon-based releases. Distribution of this contaminant follows the scheme of potential sources of contamination with petroleum product allocation (Fig. 4).

\subsection{Health risk evaluation of PAHs in soils}

Health risks associated with soil contamination from PAHs was assessed using the benzo(a)pyrene total potency equivalents approach $\left(\mathrm{BaP}_{\mathrm{eq}}\right)$. The $\mathrm{BaP}_{\mathrm{eq}}$ for a soil sample is simply calculated by multiplying the concentration of each PAH in the sample by its benzo(a)pyrene TEF, given in Table 6 .

The calculated $\mathrm{BaP}_{\mathrm{eq}}$ on the average concentration of $15 \mathrm{PAH}$ (here and after referred to as $\mathrm{BaP}_{\mathrm{eq}}-15 \mathrm{PAH}$ ) varied between 0.44 and $0.66 \mathrm{mg} \mathrm{kg}^{-1}$ of dry soil. The highest $\mathrm{BaP}_{\mathrm{eq}}-15 \mathrm{PAH}$ mean concentrations were found in residential and industrial areas: 0.66 and $0.55 \mathrm{mg} \mathrm{kg}^{-1}$, respectively. Parkland areas are characterized by lower but still considerable levels of BaPeq-15 PAH (mean $0.44 \mathrm{mg} \mathrm{kg}^{-1}$ ). Note that one single sample taken from Kirovsky parkland exhibited a total $\mathrm{BaP}_{\mathrm{eq}}$ concentration of $1.84 \mathrm{mg} \mathrm{kg}^{-1}$ (The Park of 9th January), which evidently shows that parkland land uses are subjected to a high load of PAHs as well as other land uses. Obtained values are several times higher than reported total PAH carcinogenic potencies in a number of studies ( $\mathrm{BaP}_{\text {eq }}$ of total PAHs): $0.02 \mathrm{mg} \mathrm{kg}^{-1}$ in soils of Viseu and $0.23 \mathrm{mg} \mathrm{kg}^{-1}$ in Lisbon, Portugal (Cachada et al., 2012); Nadal et al., (2004) reported $\mathrm{BaP}_{\mathrm{eq}}$ concentrations varying between 0.02 and $0.12 \mathrm{mg} \mathrm{kg}^{-1}$ in soils of Tarragona Province, Spain; $0.18 \mathrm{mg} \mathrm{kg}^{-1}$ in soils of Beijing and $0.24 \mathrm{mg} \mathrm{kg}^{-1}$ in Shanghai, China (Liu et al., 2010; Wang et al., 2013).

Finally, obtained BaP total potency equivalents of PAHs were compared with soil quality guideline values for direct contact with contaminated soil with respect to particular land use (CCME, 2010), setting out the safe level of $0.6 \mathrm{mg} \mathrm{kg}^{-1} \mathrm{BaP}_{\mathrm{eq}}$ (for each land use). The reported $\mathrm{BaP}_{\mathrm{eq}}$ of the $15 \mathrm{PAH}$ concentrations was above the safe level of $0.6 \mathrm{mg} \mathrm{kg}^{-1}$. Exposure to these soils through direct contact

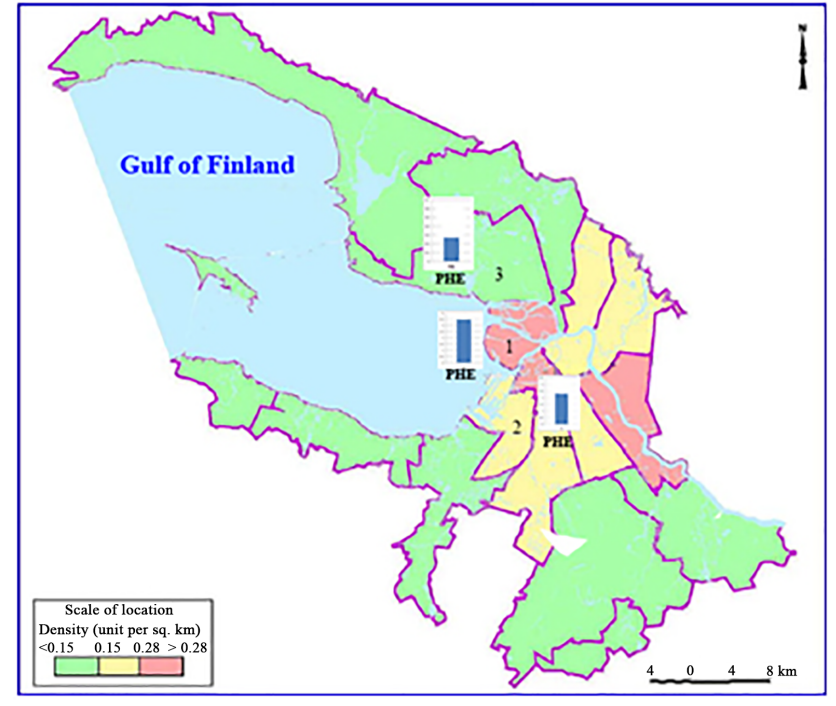

Figure 4. Scale of potential sources of contamination with petroleum products (units per square kilometre) with PHE distribution plots.

probably poses a significant risk to human health from carcinogenic effects of PAHs, even in urban parklands. Obtained values of $\mathrm{BaP}_{\mathrm{eq}}$ were further used to calculate the index of incremental lifetime cancer risk (ILCR). This method provides quantitative evaluation of the human exposure to PAHs through various exposure scenarios including ingestion, dermal contact and inhalation of different age and gender groups.

The acceptable level of ILCR is set at $10^{-6}-10^{-4}$ by the US EPA (US EPA, 2001). Risks below $10^{-6}$ do not require further action, while risks above $10^{-4}$ are considered concerning and require additional action to reduce the exposure and resulting risk (US EPA, 2004). Calculated values of TILCR are summarized in Table 7.

All estimated TILCRs were within the acceptable range $\left(10^{-6}-10^{-4}\right)$. The TILCRs for different exposure pathways decreased in the following order: ingestion $>$ dermal contact $>$ inhalation for both children and adults. The greatest TILCR value was estimated for soil ingestion in the case of residential land use $\left(4.25 \times 10^{-5}\right)$, followed by industrial land use $\left(8.41 \times 10^{-6}\right)$. Soil ingestion is considered to be the most significant route of exposure in residential areas, particularly for children since they are more naturally active than other age groups, which leads to greater CR caused by soil ingestion (Wang et al., 2015). The estimated TILCRs caused by dermal contact with soil and inhalation for both the children and adult groups were smaller than those caused by ingestion of soil particles, ranging from $10^{-6}$ to $10^{-12}$. The applied RAIS model does not provide an estimation of CR for youths, though this age group is supposed to be more vulnerable for dermal contact with contaminated soil, which accounts for $32.5 \%$ of the exposure, followed by the CRs for 
Table 6. PAH concentrations in urban soils, expressed in $\mathrm{BaP}_{\mathrm{eq}}, \mathrm{mg} \mathrm{kg}^{-1}$.

\begin{tabular}{|c|c|c|c|c|c|c|c|c|c|c|}
\hline \multirow[t]{2}{*}{ Compound } & \multicolumn{3}{|c|}{ Parkland } & \multicolumn{3}{|c|}{ Residential } & \multicolumn{3}{|c|}{ Industrial } & \multirow[t]{2}{*}{$\mathrm{TEF}^{*}$} \\
\hline & Mean $\times$ TEF & $\mathrm{Max} \times \mathrm{TEF}$ & $\operatorname{Min} \times \mathrm{TEF}$ & Mean $\times$ TEF & Max $\times \mathrm{TEF}$ & Min $\times$ TEF & Mean $\times$ TEF & Max $\times$ TEF & Min $\times$ TEF & \\
\hline NAP & 0.00006 & 0.00028 & 0.00003 & 0.00005 & 0.00007 & 0.00 & 0.00009 & 0.00021 & 0.00 & 0.001 \\
\hline ANA & 0.00002 & 0.00018 & 0.00 & 0.00 & 0.00001 & 0.00 & 0.00 & 0.00003 & 0.00 & 0.001 \\
\hline FLU & 0.0001 & 0.00023 & 0.00005 & 0.00017 & 0.0004 & 0.00003 & 0.00017 & 0.00031 & 0.00006 & 0.001 \\
\hline PHE & 0.00016 & 0.00045 & 0.00005 & 0.00026 & 0.00047 & 0.00003 & 0.00036 & 0.00065 & 0.00007 & 0.001 \\
\hline ANT & 0.0006 & 0.0037 & 0.0001 & 0.0004 & 0.0011 & 0.00 & 0.0005 & 0.0009 & 0.0001 & 0.01 \\
\hline FLT & 0.00018 & 0.00035 & 0.00009 & 0.00069 & 0.00149 & 0.00004 & 0.00072 & 0.0015 & 0.00011 & 0.001 \\
\hline PYR & 0.00018 & 0.00035 & 0.00009 & 0.00074 & 0.00167 & 0.00004 & 0.0007 & 0.0015 & 0.00016 & 0.001 \\
\hline $\mathrm{BaA}$ & 0.019 & 0.053 & 0.004 & 0.035 & 0.064 & 0.002 & 0.03 & 0.067 & 0.007 & 0.10 \\
\hline CHR & 0.0015 & 0.0044 & 0.0001 & 0.0031 & 0.0069 & 0.0002 & 0.0028 & 0.0054 & 0.0007 & 0.01 \\
\hline $\mathrm{BbF}$ & 0.023 & 0.069 & 0.005 & 0.046 & 0.084 & 0.002 & 0.041 & 0.10 & 0.01 & 0.10 \\
\hline $\mathrm{BkF}$ & 0.015 & 0.0560 & 0.002 & 0.019 & 0.036 & 0.001 & 0.016 & 0.033 & 0.004 & 0.10 \\
\hline $\mathrm{BaP}$ & 0.22 & 0.7 & 0.04 & 0.43 & 0.87 & 0.02 & 0.34 & 0.73 & 0.07 & 1.00 \\
\hline DBA & 0.15 & 0.90 & 0.00 & 0.10 & 0.20 & 0.00 & 0.10 & 0.40 & 0.00 & 5.00 \\
\hline BPE & 0.0017 & 0.0046 & 0.0004 & 0.0029 & 0.0052 & 0.0001 & 0.0027 & 0.0069 & 0.0006 & 0.01 \\
\hline IPY & 0.012 & 0.049 & 0.00 & 0.017 & 0.045 & 0.001 & 0.015 & 0.038 & 0.00 & 0.10 \\
\hline$\sum 15 \mathrm{PAH}$ & 0.4435 & 1.84154 & 0.05191 & 0.65531 & 1.31631 & 0.02644 & 0.55004 & 1.3854 & 0.0928 & \\
\hline$\sum 7$ PAH* $^{*}$ & 0.4405 & 1.8314 & 0.0511 & 0.6501 & 1.3059 & 0.0262 & 0.5448 & 1.3734 & 0.0917 & \\
\hline
\end{tabular}

*Values of the toxic equivalency factors proposed by Nisbet and Lagoy (1992).

Table 7. Calculated TILCRs based on different routes of exposure and land use scenarios (sum of children and adults).

\begin{tabular}{|c|c|c|c|c|c|}
\hline \multirow[t]{2}{*}{ Land use scenario } & \multirow[b]{2}{*}{ Route of exposure } & \multicolumn{4}{|c|}{ Total incremental lifetime cancer risk (unitless) } \\
\hline & & Ingestion & Dermal & Inhalation & Total risk \\
\hline Parkland & & $6.16 \times 10^{-7}$ & $1.71 \times 10^{-7}$ & $2.05 \times 10^{-12}$ & $7.77 \times 10^{-7}$ \\
\hline Residential & & $4.24 \times 10^{-5}$ & $1.24 \times 10^{-6}$ & $2.83 \times 10^{-8}$ & $4.36 \times 10^{-5}$ \\
\hline Industrial (composite worker) & & $8.41 \times 10^{-6}$ & - & $1.98 \times 10^{-7}$ & $8.61 \times 10^{-6}$ \\
\hline
\end{tabular}

children and adults, accounting for 27.6 and $21.8 \%$, respectively, suggesting that dermal contact could be a significant exposure pathway for youths compared to children and adults (Wang et al., 2015). Exposure route related to dermal contact with soil in industrial areas was not assessed, considering that skin of the workers is not exposed.

\section{Conclusions}

Results of the study demonstrated that soils within studied urban areas are characterized by common levels of total PAHs generally attributed to high traffic density of the city. Considerable levels of soil contamination with PAHs were noted. The common tendency in PAH distribution patterns between investigated sites clearly indicates the common source of PAHs in urban soils. A larger portion of highmolecular-weight PAHs along with determined molecular ratios suggest the predominance of pyrogenic sources, mainly attributed to combustion of gasoline, diesel and oil. Petrogenic sources of PAHs also have a significant portion defining the predominance of low-molecular-weight PAHs associated with petroleum, such as phenanthrene. Derived concentrations of seven carcinogenic PAHs as well as calculated
$\mathrm{BaP}$ total potency equivalents were multiple times higher than reported in a number of other studies, indicating a significant risk for human health in the case of direct contact. However application of the RAIS CR evaluation module revealed that incremental lifetime risks posed to the population are under the acceptable range $\left(10^{-4}-10^{-6}\right.$ and lower). Oneway ANOVA results showed significant differences in levels of 15 PAHs, 7 PAHs, FLU, PHE, FLT, PYR, BaA, CHR, $\mathrm{BbF}, \mathrm{BaP}$ and $\mathrm{BPE}$ among parkland, residential and industrial land uses, suggesting the influence of land use factor on distribution of PAHs in soils of the city. Further study with an application of complex statistical methods such as principal component analysis, which would contribute to precision of PAH sources allocation, is needed.

Data availability. Data can be accessed at https://drive.google. com/open?id=18UCcZNp0_qzXHpXsW-O3jKYqPidiozbX (Shamilishvily et al., 2018).

The Supplement related to this article is available online at https://doi.org/10.5194/se-9-669-2018-supplement. 
Competing interests. The authors declare that they have no conflict of interest.

Acknowledgements. Saint Petersburg University grant no. 1.37.151.2014 and Saint Petersburg State University Internal Grant for the Modernization of Scientific Equipment no. 1.40.541.2017.

Edited by: Martine van der Ploeg

Reviewed by: four anonymous referees

\section{References}

Abakumov, E. V., Lodygin, E. D., Gabov, D. A., and Krylenkov, V. A.: Polycyclic aromatic hydrocarbons content in Antarctica soils as exemplified by the Russian polar stations, Gigiena i sanitariia, 1, 31-35, 2014.

Abakumov, E. V., Parnikoza, I. Y., Lupachev, A. V., Lodygin, E. D., Gabov, D. N., and Kunakh, V. A.: Content of polycyclic aromatic hydrocarbons in soils of Antarcti stations regions, Gigiena i saniataria, 94, 20-25, 2015.

ATSDR: Polycyclic Aromatic Hydrocarbons, Agency for Toxic Substances and Disease Registry, available at: https://www.atsdr. cdc.gov/toxprofiles/tp.asp?id=122\&tid=25 (last access: $24 \mathrm{Au}-$ gust 2015), 1995.

BBodSchV: Bundes- Bodenschutz- und Altlastenverordnung (Bundesbodenschutzverordnung -BBodSchV), available at: http:// www.gesetze-im-internet.de/bundesrecht/bbodschv/gesamt.pdf (last access: 6 September 2015), 1999.

Belousova V. A., Berezin I. K., Golovina N. M., Grigoriev A. S., Gromyko M. O., Guchinsky V. A., Dvinyanina O. V., Zavyalov D. V., Zaporozhets A. I., Ipatova S. V., Karetnikova T. V., Kerenkov G. A., Kovaleva T. V., Konstantinova O. V., Korobeinikova M. A., Krapivko N. A., Kruglov F. V., Krutoy D. M., Kryakova E. O., Kuptsova N. M., Kurnosov D. V., Lyakhovnenko S. F., Men'shova Yu. A., Miloslavskaya Yu. G., Morozova I. A., Mozhsenikova N. B., Pakudina V. N., Parfenova A. V., Romanova T. V., Rublevsky V. V., Rutkovskiy A. M., Rybakova Yu.V., Savenkova G. B., Sergeeva N. A., Serebritsky I. A., Silina I. V., Smirnov N.A., Strakhov M. A., Stukkei G. A., Suchkova L. I., Titorenko A. A., Fomina L. B., Frumin G. T., Khmylev I. V., Shpakova E. N., Shulga L. V., and Shundrina Yu. A.: Report on the environmental situation in St. Petersburg in 2014, The Committee for Nature Use, Environmental Protection, and Ecological Safety of St. Petersburg, St. Petersburg, Russia, http://gov.spb.ru/static/writable/ ckeditor/uploads/2015/06/19/doklad_2014_SWipmNU.pdf, last access: 11 September 2015.

Berset, J. D., Ejem, M., Holzer, R., and Lischer, P.: Comparison of different drying, extraction and detection techniques for the determination of priority polycyclic aromatic hydrocarbons in background contaminated soil samples, Anal. Chim. Acta., 383, 263-275, 1999.

Bucheli, T. D., Blum, F., Desaules, A., and Gustafsson Ö: Polycyclic aromatic hydrocarbons, black carbon, and molecular markers in soils of Switzerland, Chemosphere, 56, 1061-1076, 2004.
Budzinski, H., Jones, I., Bellocq, J., Pierard, C., and Garrigues, P. H.: Evaluation of sediment contamination by polycyclic aromatic hydrocarbons in the Gironde estuary, Mar. Chem., 58, 85-97, 1997.

Cachada, A., Pato, P., Rocha-Santos, T., da Silva, E. F., and Duarte, A. C.: Levels, sources and potential human health risks of organic pollutants in urban soils, Sci. Total. Environ., 430, 184192, 2012.

CCME: Polycyclic aromatic hydrocarbons, Canadian soil quality guidelines for protection of environmental and human health, Canadian Council of Ministers of the Environment, available at: http://ceqg-rcqe.ccme.ca/en/index.html (last access: 20 September 2015), 2010.

Choi, H. G., Moon, H. B., Choi, M., Yu, J., and Kim, S. S.: Mussel watch program for organic contaminants along the Korean coast, 2001-2007, Environ. Monit. Assess., 169, 473-474, 2010.

Chung, N. and Alexander, M.: Differences in sequestration and bioavailability of organic compounds aged in dissimilar soils, Environ. Sci. Technol., 32, 855-860, 1998.

Dashko, R. E., Aleksandrova, O. U., Kotyukov, P. V., and Shidlovskaya, A. V.: Features of the engineering-geological conditions of St. Petersburg, Journal of Urban development and Geotechnical Engineering, 13, 25-71, 2011.

Duggan, M. and Strehlow, C. D.: Contaminants in Soil: Collation of Toxicological Data and Intake Values for Humans: Benzo[a]pyrene, Department for Environment, Food and Rural Affairs and the Environment Agency, London, 140 pp., 1995.

Eschenbach, A., Wienberg, R., and Mahro, B.: Fate and stability of nonextractable residues of [14C]PAH in contaminated soils under environmental stress conditions, Environ. Sci. Technol., 32, 2585-2590, 1998.

Essumang, D. K., Kowalski, K., and Sogaard, E. G.: Levels, distribution and source characterization of polycyclic aromatic hydrocarbons (PAHs) in topsoils and roadside soils in Esbjerg, Denmark, Bull. Environ. Contam. Toxicol., 86, 438-443, 2011.

Gabov, D. N., Beznosikov, V. A., and Kondratenko, B. M.: Polycyclic aromatic hydrocarbons in background podzolic and gleyic peat-podzolic soils, Eurasian Soil Sci.+, 40, 256-264, 2007.

Gabov, D. N., Beznosikov, V. A., Kondratenko, B. M., and Yakovleva, E. V.: Formation of polycyclic aromatic hydrocarbons in northern and middle taiga soils, Eurasian Soil Sci.+, 41, 11801188, 2008.

Gagarina, E. I., Rastvorova, O. G., Schastnaya, L. S., Kasatkina, G. A., Fedorova, N. N., Chukov, S. N., and Rusakov, A. V.: Soils of the Russian plain natural zones: a textbook, Publishing of the St. Petersburg State University, St. Petersburg, 120 pp., 2008.

Gorky, A. V. and Petrova, E. A.: Pollution of St. Petersburg with organic toxicants, Report of RGEC of FSUE "Urangeo" of the Ministry of Natural Resources of the Russian Federation, 21 pp., 2012

GOST 17.4.4.02-84: Nature protection. Soils. Methods for sampling and preparation of soils for chemical, bacteriological, helmintological analysis, Moscow, 8 pp., 1984 (in Russian).

Guo, W., He, M. C., Yang, Z. F., Zhang, H. Y., Lin, C. Y., and Tian, Z. J.: The distribution, sources and toxicity risks of polycyclic aromatic hydrocarbons and $n$-alkanes in riverine and estuarine core sediments from Daliao River watershed, Environ. Earth. Sci., 68, 2015-2024, 2013. 
Haritash, A. K. and Kaushik, C. P.: Biodegradation aspects of polycyclic aromatic hydrocarbons (PAHs): a review, J. Hazard. Mater., 169, 1-15, 2009.

Havelcová, M., Melegy, A., and Rapant, S.: Geochemical distribution of polycyclic aromatic hydrocarbons in soils and sediments of El-Tabbin, Egypt. Chemosphere, 95, 63-74, 2014.

HELCOM: BASE project 2012-2014: Preparation of biodiversity and hazardous substances indicators with targets that reflect good environmental status for HELCOM (including the HELCOM CORESET project) and improvement of Russian capacity to participate in operationalization of those indicators, http://helcom.fi/Lists/Publications/INDICATORS_Russian\% 20capacity $\% 20$ to $\% 20$ participate $\% 20$ in $\% 20$ operationalization $\%$ 20of\%20CORESET\%20indicators.pdf (last access: June 2016), 2014

Hwang, S. and Cutright, T. J.: Biodegradability of aged pyrene and phenanthrene in a natural soil, Chemosphere 47, 891-899, 2002.

Hwang, H. M., Wade, T. L., and Sericano, J. L.: Concentrations and source characterization of polycyclic aromatic hydrocarbons in pine needles from Korea, Mexico, and United States, Atmos Environ, 37, 2259-2267, 2003.

ISO 10381-1: Soil quality. Sampling. Part 1: Guidance on the design of sampling programmes, available at: http://docs.cntd.ru/ document/1200074384 (last access: June 2016), 2002.

Johnsen, A. R., Wick, L. Y., and Harms, H.: Principles of microbial PAH-degradation in soil, Environ. Pollut., 133, 710-84, 2005.

Kalf, D. F., Crommentuijn, T., and van de Plassche, E. J.: Environmental quality objectives for 10 polycyclic aromatic hydrocarbons (PAHs), Ecotox. Environ. Safe., 36, 89-97, 1997.

Liu, S., Xia, X., Yang, L., Shen, M., and Liu, R.: Polycyclic aromatic hydrocarbons in urban soils of different land uses in Beijing, China: distribution, sources and their correlation with the city's urbanization history, J. Hazard. Mater., 177, 1085-1092, 2010

Lodygin, E. D., Chukov, S. N., Beznosikov, V. A., and Gabov, D. N.: Polycyclic aromatic hydrocarbons in soils of Vasilievsky Island (St. Petersburg), Eurasian Soil Sci+., 41, 1321-1326, 2008.

Mackay, D. and Hickie, B.: Mass balance model of source apportionment, transport 482 and fate of PAHs in Lac Saint Louis, Quebec, Chemosphere, 41, 681-692, 2000.

Marr, L. C., Kirchstetter, T. W., Harley, R. A., Miguel, A. H., Hering, S. V., and Hammond, S. K.: Characterization of polycyclic aromatic hydrocarbons in motor vehicle fuels and exhaust emissions, Environ. Sci. Technol., 33, 3091-3099, 1999.

Marusenko, Y., Herckes, P., and Hall, S. J.: Distribution of polycyclic aromatic hydrocarbons in soils of an arid urban ecosystem. Water Air Soil Poll., 219, 473-487, 2011.

Michéli, E., Schad, P., Spaargaren, O., Dent, D., and Nachtergaele, F.: World reference base for soil resources: 2006: a framework for international classification, correlation and communication (FAO), IUSS Working Group WRB, World reference base for soil resources, World Soil Resources Reports No. 103, FAO, Rome, 143 pp., 2006.

Mielke, H. W., Wang, G., Gonzales, C. R., Le, B., Quach, V. N., and Mielke, P. W.: PAH and metal mixtures in New Orleans soils and sediments, Sci. Total Environ., 281, 217-227, 2001

Morillo, E., Romero, A. S., Maqueda, C., Madrid, L., AjmoneMarsan, F., Grcman, H., and Villaverde, J: Soil pollution by
PAHs in urban soils: a comparison of three European cities, J. Environ. Monit., 9, 1001-1008, 2007.

Nadal, M., Schuhmacher, M., and Domingo, J. L.: Levels of PAHs in soil and vegetation samples from Tarragona County, Spain, Environ. Pollut., 132, 1-11, 2004.

Nisbet, I. C. and LaGoy, P. K.: Toxic equivalency factors (TEFs) for polycyclic aromatic hydrocarbons (PAHs), Regul. Toxicol. Pharmacol., 16, 290-300, 1992.

OEHHA (Office of Environmental Health Hazard Assessment): Expedited Cancer Potency Factors and Proposed Regulatory Levels for Certain Proposition 65 Carcinogens, Air Resources Board and OEHHA, California EPA, Sacramento, CA, USA, 45 pp. 1992.

Pandey, P. K., Patel, K. S., and Lenicek, J., Polycyclic aromatic hydrocarbons: need for assessment of health risks in India, Study of an urban-industrial location in India, Environ. Monit. Assess., 59, 287-319, 1999.

Park, K. S., Sims, R. C., and Dupont, R. R.: Transformation of PAHs in soil systems, J. Environ., 522, 632-636, 1990.

PND F 16.1:2:2.2:3.62-09: Quantitative chemical analysis of soil. Methods of measurement of the mass fraction of polycyclic aromatic hydrocarbons in soil, sediments, sewage sludge and industrial wastes by HPLC, Moscow, Russia. 23 pp., 2009 (in Russian).

Prahl, F. G. and Carpenter, R.: Polycyclic aromatic hydrocarbon (PAH)-phase associations in Washington coastal sediment, Geochim. Cosmochim. Ac., 47, 1013-1023, 1983.

Rehwagen, M., Müller, A., Massolo, L., Herbarth, O., and Ronco, A.: Polycyclic aromatic hydrocarbons associated with particles in ambient air from urban and industrial areas, Sci. Total Environ., 348, 199-210, 2005.

Rusakov, A. V., Sedov, S. N., and Ivanova, K. A.: Micromorphological characterization of buried paleosols of the historic center Proceedings of the scientific conference: Ecology of St. Petersburg and its surroundings, Publishing of the St. Petersburg State University, St. Petersburg, Russia, 80-82, 2005 (in Russian).

Shamilishvily, G., Abakumov, E., and Gabov, D.: Polycyclic aromatic hydrocarbon in urban soils of an Eastern European megalopolis: distribution, source identification and cancer risk evaluation, available at: https://drive.google.com/open?id= 18UCcZNp0_qzXHpXsW-O3jKYqPidiozbX, last access: 8 May 2018.

Shishov, L. L., Tonkonogov, V. D., Lebedeva, I. I., and Gerasimova, M. I: Classification and diagnostics of Russian soils, Oikumena, Smolensk, 56, 2004.

Stroganova, M. N. and Agarkova, M. G.: Urban Soils: Experience of Study and Systematics (by Example of Soils of Southwestern Part of Moscow), Soil. Sci., 7, 16-24, 1992.

Tang, L., Tang, X. Y., Zhu, Y. G., Zheng, M. H., and Miao, Q. L.: Contamination of polycyclic aromatic hydrocarbons (PAHs) in urban soils in Beijing, China, Environ. Int., 31, 822-828, 2005.

Trapido, M.: Polycyclic aromatic hydrocarbons in Estonian soil: contamination and profiles, Environ. Pollut., 105, 67-74, 1999.

Ufimtseva, M. D., Terekhina, N. V., and Abakumov, E. V.: Fizikokhimicheskayakharakteristikaurbanozemovtsentral'nogoraiona Sankt-Peterburga, Vestnik Sankt-Peterburgskogouniversiteta, 7, 85-97, 2011 (in Russian).

US EPA: Provisional Guidance for Quantitative Risk Assessment of PAH, National Service Center for Environmental Publica- 
tions (NSCEP) of the US Environmental Protection Agency, Washington DC: Office of Health and Environmental Assessment, available at: http://nepis.epa.gov/Exe/ZyPURL.cgi? Dockey=30002TUA.txt (last access: 20 April 2015, 1993.

US EPA Method 8310: Polynuclear Aromatic Hydrocarbons, in: Test Methods for Evaluating Solid Waste, Physical/Chemical Methods; Third Edition; Final Update 3-A, National Service Center for Environmental Publications (NSCEP) of the US Environmental Protection Agency, Washington DC: Office of Health and Environmental Assessment, Revision 0, available at: http://nepis.epa.gov/Exe/ZyPURL.cgi?Dockey= 50000U6E.txt (last access: 20 April 2015), 1996a.

US EPA Method 3550b: Ultrasonic extraction, in: Test Methods for Evaluating Solid Waste, Physical/Chemical Methods; Third Edition; Final Update 3-A, National Service Center for Environmental Publications (NSCEP) of the US Environmental Protection Agency, Washington DC: Office of Health and Environmental Assessment, Revision 2, availabel at: http://nepis.epa.gov/ Exe/ZyPURL.cgi?Dockey=50000U6E.txt (last access: 20 April 2015), 1996b.

US EPA Method 3630c: Silica Gel Cleanup, in: Test Methods for Evaluating Solid Waste, Physical/Chemical Methods; Third Edition; Final Update 3-A, National Service Center for Environmental Publications (NSCEP) of the US Environmental Protection Agency, Washington DC: Office of Health and Environmental Assessment, Revision 3, available at: http://www3.epa.gov/epawaste/hazard/testmethods/ sw846/pdfs/3630c.pdf (last access: 20 April 2015), 1996c.

US EPA: Polycyclic Organic Matter, in: US EPA official web site, US Environmental Protection Agency, Washington DC: Office of Health and Environmental Assessment, available at: http:// www3.epa.gov/ttn/atw//hlthef/polycycl.html (last access: $30 \mathrm{Au}-$ gust 2015), 2002.

US EPA: Guidance for Conducting Health Risk Assessment of Chemical Mixtures, in: Risk Assessment Forum Technical Panel Report (External Scientific Peer Review Draft), National Center for Environmental Assessment (NCEA) of the US Environmental Protection Agency, available at: http://cfpub.epa.gov/si/si_ public_file_download.cfm?p_download_id=36583. (last access: 10 September 2015), 1999.

US EPA: Risk assessment guidance for Superfund: volume IIIpart A, process for conducting probabilistic risk assessment, EPA 540-R-02-002, US Environmental Protection Agency (US EPA), Washington, DC, 35 pp., 2001.
US EPA (U.S. Environmental Protection Agency): Risk Assessment Guidance for Superfund: Volume Ihuman health evaluation manual (part E, supplemental guidance for dermal risk assessment), EPA/540/R/99/005, Office of Superfund Remediation and Technology Innovation, Washington, DC, 41 pp., 2004.

Verbruggen, E. M. J., Posthumus, R., and Van Wezel, A. P.: Ecotoxicological Serious Risk Concentrations for soil, sediment and (ground) water: updated proposals for first series of compounds, in: RIVM report 711701 20, National Institute of Public Health and the Environment, the Netherlands, available at: http://www. pbl.nl/sites/default/files/cms/publicaties/711701020.pdf (last access: 10 September 2015), 2001.

Wang, X. T., Miao, Y., Zhang, Y., Li, Y. C., Wu, M. H., and Yu, G.: Polycyclic aromatic hydrocarbons (PAHs) in urban soils of the megacity Shanghai: occurrence, source apportionment and potential human health risk, Sci. Total. Environ., 447, 80-89, 2013.

Wang, C., Wu, S., Zhou, S., Wang, H., Li, B., Chen, H, and Shi, Y. : Polycyclic aromatic hydrocarbons in soils from urban to rural areas in Nanjing: concentration, source, spatial distribution, and potential human health risk, Sci. Tot. Environ., 527, 375-383, 2015.

Wang, C., Wu, S., Zhou, S., Shi, Y, and Song, J..: Characteristics and Source Identification of Polycyclic Aromatic Hydrocarbons (PAHs) in Urban Soils: A Review, Pedosphere, 27, 17-26, 2017.

Weiss, P., Riss, A., Gschmeidler, E., and Schentz, H.: Investigation of heavy metal, $\mathrm{PAH}, \mathrm{PCB}$ patterns and PCDD/F profiles of soil samples from an industrialized urban area (Linz, Upper Austria) with multivariate statistical methods, Chemosphere, 29, 22232236, 1994.

Wilcke, W., Zech, W., and Kobža, J.: PAH-pools in soils along a PAH-deposition gradient, Environ. Pollut., 92, 307-313, 1996.

Wilcke, W.: Synopsis polycyclic aromatic hydrocarbons (PAHs) in soil - a review, J. Plant. Nutr. Soil. Sci., 163, 229-248, 2000.

Wild, S. R. and Jones, K. C.: Polynuclear aromatic hydrocarbons in the United Kingdom environment: a preliminary source inventory and budget, Environ. Pollut., 88, 91-108, 1995.

Yang, H. H., Lai, S. O., Hsieh, L. T., Hsueh, H. J., and Chi, T. W.: Profiles of PAH emission from steel and iron industries, Chemosphere, 48, 1061-1074, 2002.

Yu, H.: Environmental carcinogenic polycyclic aromatic hydrocarbons: photochemistry and phototoxicity, J. Environ. Sci. Heal. C., 20, 149-183, 2002.

Yunker, M. B., Macdonald, R. W., Vingarzan, R., Mitchell, R. H, Goyette, D., and Sylvestre, S.: PAHs in the Fraser River basin: a critical appraisal of PAH ratios as indicators of PAH source and composition, Org. Geochem., 33, 489-515, 2002. 